\title{
A questão do ateísmo para o entendimento do homem no pensamento de Viktor Frankl
}

\author{
The question of atheism for the understanding of man in the thought of \\ Viktor Frankl
}

\section{RESUMO}

objetivo do presente artigo foi demonstrar a importância da questão do ateísmo para o entendimento do homem no pensamento de Viktor Frankl. Para tanto, discorreu-se acerca da concepção do autor sobre o fenômeno do ateísmo em suas principais obras, e fez-se um contraponto com as concepções de outros autores que abordaram a temática. Frankl abordou o ateísmo em uma perspectiva existencial sob o ponto de vista da Logoterapia, e adotou uma postura fenomenológica para tratar da questão. Em conclusão, apontou-se a liberdade e a consciência como elementos comuns entre teístas e ateístas, o que proporcionou um diálogo integrador entre crentes e irreligiosos.

Palavras-chave: Ateísmo; Sentido da Vida; Psicologia da Religião.

\section{ABSTRACT}

This article aims to demonstrate the importance of Atheism to the comprehension of man according to the thought of Viktor Frankl. In order to achieve this goal the article presented the author's conception about the phenomenon of Atheism in his main works, comparing it with the conceptions of other authors who have dealt with the same theme. Frankl talked about Atheism from an Existentialist perspective, according to the viewpoint of Logotherapy. His outlook can also be considered a phenomenological one. In its conclusion the article points to both freedom and conscience as common elements to Theists and Atheists, providing an integrating dialog between believers and non-religious people.

Key-words: Atheism; meaning of life; Psychology of Religion.

1 Professor Associado do Departamento de Ciências das Religiões da Univerisidade Federal da Paraíba.

Contato: logosvitae@ hotmail.com .

2 Doutoranda no Programa de Pós Graduação em Ciências das Religiões da Universidade Federal da Paraíba.

Contato: josileneufpb@gmail.com . Submetido em 06/08/2018; aceito em 05/04/2019. 


\section{Introdução}

O presente ensaio analisou a perspectiva do ateísmo no pensamento de Viktor Frankl, o qual defendeu que a motivação primária do ser humano seria a vontade de sentido, seja para o homem religioso ou não. Ademais, abordou em sua obra a questão do ateísmo, mantendose com uma postura fenomenológica, posto que tratou o fenômeno da irreligiosidade apenas como um objeto de estudo.

Constata-se que o tema do ateísmo é pouco explorado entre os logoterapeutas, por esse motivo torna-se importante clarificar essa temática na ótica da análise existencial frankliana. Outrossim, elencam-se duas justificativas para discorrer sobre o ateísmo na Logoterapia: 1) A carência de textos e publicações que abordem a perspectiva do ateísmo na logoterapia e análise existencial; 2) A necessidade de compreender a visão da Logoterapia acerca do homem não-religioso. Dessa forma, o objetivo do presente artigo foi demonstrar a importância da questão do ateísmo para o entendimento do homem no pensamento de Viktor Frankl.

De forma geral, "o ateísmo não é simplesmente a rejeição da existência de Deus. Embora possa parecer estranho, a descrença em Deus é apenas um aspecto, e não necessariamente $\mathrm{o}$ aspecto principal, da maneira como o ateísta reflexivo pensa na realidade" (WALTERS, 2015, p. 16). Nesse sentido, o autor clarifica que o ateísmo designa na verdade a rejeição ao teísmo, "quando a-teístas negam a existência de Deus, seu ceticismo é dirigido ao Deus teísta e seus argumentos" (WALTERS, 2015, p. 16). Frankl, por sua vez, tenta superar essa visão dicotômica entre ateus e teístas, por meio de uma compreensão suprarreligiosa

O tema do ateísmo está enraizado na própria vida de Frankl, pois ele passou por um período na sua adolescência que se considerava ateu. Ele mesmo afirma que: "quando criança era crente, mas depois, na puberdade, passei também por uma fase ateísta." (FRANKL, 2010, p. 65). Frankl também foi apontado como ateu por parte de um sacerdote de Viena. Ele narra o seguinte:

[...] certo dia, passo diante da Igreja Votiva, em Viena, que sempre amei tanto. Embora não seja uma igreja gótica original, é totalmente construída nesse estilo. Até essa data, nunca havia entrado lá, mas ao ouvir os sons do órgão, sugiro à minha mulher entrar e nos sentarmos um pouco.

Mal entramos, a música cessa, o padre se aproxima do púlpito e começa o sermão. E ele fala da [rua] Berggasse 19 e do "ateu" Sigmund Freud. Depois ele diz:

- Mas não precisamos nem ir tão longe, até a Berggasse. Logo aqui atrás, na Mariannengabe 1, mora Viktor Frankl, ele escreveu um livro, Psicoterapia $e$ sentido da vida, na verdade um livro "ateu". (FRANKL, 2010, p. 65-66)

Se por um lado Frankl é acusado de ser ateu, por outro, é apontado como sendo excessivamente religioso. As questões religiosas assim como o ateísmo presentes no pensamento de Viktor Frankl encontram-se baseados tanto em sua teoria, a Logoterapia e Análise Existencial, e balizada como sua própria postura. "Frankl está comprometido com a neutralidade médica [...] e, portanto, a logoterapia assume uma posição neutra sobre a questão religiosa, de modo que há espaço para o ser humano religioso (de qualquer crença) e também, como temos visto, para o agnóstico e o ateu"3 (VISIERS WÜRTH, 2007, p. 42 - tradução nossa). Ou seja, a sua visão antropológica, caracterizada pela neutralidade científica, abarca tanto a pessoa religiosa (de qualquer denominação ou vertente religiosa) quanto não religiosa de qualquer orientação.

3 “[...] Frankl está comprometido con la neutralidad médica [...], y por ello la logoterapia asume una posición neutral frente a la cuestión religiosa, por lo que hay lugar en ella para el ser humano religioso (de cualquier creencia) y también, como hemos visto, para el agnóstico y el ateo." (VISIERS WÜRTH, 2007, p. 42) 


\title{
Monantropismo e dimensão noológica: elementos comuns entre religiosos e não-religiosos
}

A antropologia de Frankl exalta acima de qualquer outra coisa a própria condição humana enquanto unidade, um gênero único, e com isso ele desenvolve a ideia de um monantropismo. Segundo ele, "a humanidade desenvolveu o monoteísmo. Hoje, um outro passo se faz exigir. Eu o chamaria de 'monantropismo'. Não a crença em um Deus único, mas, mais do que isso, a consciência da unidade do gênero humano; uma unidade sob cuja luz as diferentes cores de nossa pele desapareciam" (FRANKL, 2011, p. 124). Assim, compreende-se que a distinção entre ateus, agnósticos e teístas desapareceriam.

O conceito de monantropismo seria o ponto de partida para a abordagem do ateísmo na concepção de Frankl. A valorização do gênero humano enquanto uma unidade faz com que as diferentes posições em relação ao sagrado fiquem em segundo plano. A humanidade precisa ressaltar aquilo que a une, ou aquilo que dá identidade enquanto espécie única, como por exemplo a preocupação com valores e o anseio por um sentido na vida. Em uma palavra, a autotranscendência. Segundo Frankl:

\begin{abstract}
O ser-homem significa ser dirigido no rumo de, e subordinado a, algo que é mais do que o indivíduo. A existência humana caracteriza-se pelo fato de transcender a si mesma. Tão logo a existência humana deixa de se transcender, o permanecer em vida se torna sem sentido e impossível. Foi pelo menos a lição que coube aprender [...] os prisioneiros mais aptos a suportar o cativeiro eram os que tinham algo por esperar, um objetivo no futuro, um sentido a realizar. Isso não deveria ser válido para toda a humanidade e sua sobrevivência? (FRANKL, 1978, p. 52-53)
\end{abstract}

Nesse trecho, percebe-se que a ideia de um monantropismo concebida por Frankl baseia-se fundamentalmente na perspectiva da autotranscendência e do sentido de vida, e ele complementa essa defesa argumentando que para que possamos desenvolver ou determinar valores e sentido que sejam aplicáveis a humanidade como um todo, "então a humanidade, depois de ter passado milênios sob a influência do monoteísmo, deverá dar um grande passo adiante, encaminhando-se para o saber do homem. Aquilo de que mais precisamos hoje é de um monantropismo" (FRANKL, 1978, p. 53). Ou seja, ultrapassar os limites ofertados pelos sistemas religiosos para galgar um caminho comum que respeite toda a diversidade. Por esse motivo comprende que "a religião é um fenômeno do homem, do paciente, [...] para a logoterapia, tanto a existência religiosa como a irreligiosa são, em princípio, fenômenos coexistentes. Em outras palavras, a logoterapia deve assumir perante eles uma atitude neutra" (FRANKL, 2015, p. 85).

Ou seja, os temas que se encontram relacionados à existência humana é que importam ao logoterapeuta e devem ser tratados com igualdade independentemente de sua cosmovisão devendo prevalecer a neutralidade e, por conseguinte, complementa que "o objetivo da psicoterapia é a cura psíquica - o objetivo da religião, contudo, é a salvação da alma" (FRANKL, 2015, p. 85).

Com isso ele demonstra que sua posição neutra daria ao ateu o mesmo espaço e dignidade no tratamento psicoterápico que seria dado a um religioso, o que já remete ao seu diferencial no que se refere à esse tema. Essa ideia se constata também na afirmação adiante, esclarecendo que o mais relevante para ele é o trato da dimensão religiosa enquanto instância do ser humano, mas sem privilegiar esta ou aquela denominação, inclusive tratando ateus e agnósticos como tão importantes quanto outros sistemas de crença ou filosofias de vida. Desse modo,

Deve ser esclarecido, portanto, que a logoterapia não é abordada exclusivamente, ou, obviamente, para os crentes, nem para os cristãos, nem para os católicos; 
A questão do ateísmo para o entendimento do homem no pensamento de Viktor Frankl

bem como os agnósticos ou ateus. Embora seja verdade que Frankl está muito atento à dimensão religiosa do ser humano, também é verdade que o ateísmo ou o agnosticismo não são incompatíveis com a logoterapia. ${ }^{4}$ (VISIERS WÜRTH, 2007, p. 46 - tradução nossa)

Frankl sempre se preocupou em distinguir o papel que a psicoterapia e religião teriam, colocando-as em posicionamentos que têm objetivos distintos, mas precisamos reconhecer que sua atenção dada ao tema religião sempre trouxe interpretações diversas. $O$ seu modo interdisciplinar de valorizar a todas as concepções também o fazia valorizar todos os sistemas de crença como iguais e com o mesmo valor; segundo ele, "em sua diversidade, as religiões se parecem com os diferentes idiomas: ninguém pode dizer que o seu idioma é superior ao dos demais - em todos os idiomas o homem pode aproximar-se da verdade, da única verdade, e em todos os idiomas pode ele enganar-se e até mentir" (FRANKL, 2015, p. 90).

Desse modo, o leitor pode perceber que Frankl valoriza a diversidade; nesse momento ele enfatiza a crença e/ou as religiões, mas em diversas oportunidades ele aborda com o mesmo valor a não crença, sobretudo porque o que realmente importa no âmbito da psicoterapia não é nem reprimir os sentimentos religiosos nem fazer proselitismo. Essa valorização se deve ao fato de sua psicoterapia existencial estar pautada na experiência dos aspectos da consciência de ser responsável independentemente de opção ou não opção religiosa. Até porque uma ação consciente e responsável não se restringe às pessoas que desenvolvam uma religiosidade e essa é a perspectiva de Frankl demonstrar que essas instâncias transcendem às igrejas e as suas paredes.

O que significa que todos, crentes e não crentes, podem compartilhar uma noção de ser humano como livre e responsável, e em busca de significado, uma vez que a logoterapia pode reunir precisamente diferentes sensibilidades ou ideologias. A logoterapia permite falar do humano, do espiritual no ser humano e também acreditar ou não em Deus, sem que isso suponha qualquer contradição. ${ }^{5}$ (VISIERS WÜRTH, 2007, p. 46 - tradução nossa)

De acordo com o exposto, não há contradição na concepção frankliana em tratar do espiritual no ser humano, pois não se reduz ao religioso. Isto se dá pelo fato de a ideia de espiritualidade não ter nenhuma relação direta com a fé ou crença. A dimensão espiritual para Frankl (2011) consiste sobretudo na dimensão daquilo que é especificamente humano, ou seja, aquilo que nos distingue de outras espécies. Além disso, Frankl denomina essa dimensão de noética ou noológica, termo derivado do grego, para poder distanciá-la da interpretação dada pelo senso comum como àquilo que tem relação com o espírito no sentido religioso. Destarte, o autor nos esclarece que:

Ela poderia ser igualmente definida como dimensão espiritual. No entanto, como, em língua inglesa, o termo "espiritual" [spiritual] apresenta uma conotação religiosa, [...]. O que nós compreendemos como dimensão noológica se refere a

\footnotetext{
4 "Debe aclararse por tanto que la logoterapia no se dirige exclusivamente, ni por supuesto pertencente, a los creyentes, ni a los cristianos, ni a los católicos; como tampoco a los agnósticos o ateos. Si bien es cierto que Frankl está muy atento a la dimensión religiosa del ser humano, también es cierto que no es incompatible el ateísmo ni el agnosticismo con la logoterapia." (VISIERS WÜRTH, 2007, p. 46)

5 "Lo cual significa que todos, creyentes y no creyentes, podemos compartir una noción de ser humano como ser libre y responsable, y en busca de sentido, ya que precisamente la logoterapia puede aglutinar diferentes sensibilidades o ideologias. La logoterapia permite hablar de lo humano, de lo espiritual en el ser humano y también de creer o no en dios sin que ello suponga ninguna contradicción". (VISIERS WÜRTH, 2007, p. 46)
} 
uma conceituação antropológica, muito mais do que teológica. $O$ mesmo também vale para o "logos", no contexto do termo "logoterapia". [...] Aqui, "logos" significa a humanidade do ser humano e o sentido de ser humano! (FRANKL, 2011, p. 28)

Desse modo, evidencia-se a preocupação do autor em tela em tratar dessa dimensão sem vinculação e/ou interpretação religiosa. Frankl destaca as questões relacionadas aos fenômenos tipicamente humanos presentes nessa dimensão dentre eles: a consciência. Segundo ele, "no momento em que o homem manifesta sua consciência de si, ou quando quer que exiba seu consciente, aí, o ser humano atravessa a dimensão noológica" (FRANKL, 2011, p. 28). É preciso ressaltar a relevância que tem esse elemento para Frankl; pode-se dizer que é um de seus fundamentos tendo em vista a importância que têm a consciência e a responsabilidade para a perspectiva antropológica desse autor.

\section{Consciência e Responsabilidade: preceitos para vivência harmônica entre teístas e ateístas}

Inicialmente é preciso justificar porque esses elementos são relevantes ao tratar do tema ateísmo, sobretudo na perspectiva frankliana: a primeira motivação se dá pelo fato de que todos os seres humanos são dotados destes elementos que podem ser desenvolvidos e/ou instigados pela educação; a segunda pelo fato de o próprio Frankl ter tratado dessas instâncias como pilares de sustentação de sua teoria, além das três bases comumente tratadas: a liberdade da vontade, a vontade de sentido e o sentido de vida.

Essas três bases não são o foco de nossa exposição; porém, é preciso esclarecer minimamente do que se tratam para facilitar a compreensão do que Frankl propõe com a valorização da consciência e responsabilidade. O primeiro chamado de liberdade da vontade pode ser compreendido como aquilo que promove ao homem a possibilidade de ser livre apesar dos condicionamentos impostos por diversas instâncias (psicológica, social, religiosa, entre outros). No segundo, denominado a vontade de sentido, Frankl (2016a, p. 124) defende que "a busca do indivíduo por um sentido é a motivação primária em sua vida", ou seja, seria o que move o homem no seu dia a dia, ressaltando nesse caso o fato de que encontraremos sentidos diversos, e não um sentido único.

Além disso, "o verdadeiro sentido da vida deve ser descoberto no mundo, e não dentro da pessoa humana ou de sua psique, como se fosse um sistema fechado" (FRANKL, 2016a, p. 135). Inferimos, portanto, que o encontro do sentido de vida se dá nas relações com o mundo, posto que o ser humano é um ser de relação, pois está aberto para o mundo e para um tu, distinto do seu eu.

Por fim, o terceiro pilar, o sentido da vida que "difere de pessoa para pessoa, de um dia para outro, de uma hora para outra [...] o sentido específico da vida de uma pessoa em dado momento" (FRANKL, 2016a, p. 133), que corresponde a algo concreto.

[...] a pessoa não deveria perguntar qual o sentido da sua vida, mas antes deve reconhecer que é ela que está sendo indagada. Em suma, cada pessoa é questionada pela vida; [...] à vida ela somente pode responder sendo responsável. Assim, a logoterapia vê na responsabilidade (responsibleness) a essência propriamente dita da existência humana. (FRANKL, 2016a, p. 133-134)

Observa-se que na afirmação Frankl já enfatiza a responsabilidade em sua interpretação acerca do sentido de vida de cada pessoa. Dessa forma, compreende que, independentemente de sua cosmovisão, todo ser humano é um ser responsável. Ser responsável é uma característica ontológica e não apenas uma questão de estar com a "consciência tranquila". Para Frankl é preciso que o paciente tenha plena consciência "de sua própria responsabilidade; por isso precisa deixar que ele opte pelo que, perante que ou perante quem ele se julga 
responsável" (FRANKL, 2016a, p. 134). O "perante quem" deve ser decidido livremente e pode ser a própria consciência, a sociedade ou um Deus pessoal. $O$ logoterapeuta deve deixar o caminho aberto para que seu paciente faça a sua própria escolha. $O$ autor ainda adverte que:

Toda liberdade tem um "de quê" e um "para quê". O "de quê", do qual o ser humano pode se libertar, está em seu ser impulsionado; seu eu, então, tem liberdade diante de seu id. O "para quê" da liberdade humana é sua responsabilidade. A liberdade da vontade do ser humano é, portanto, a liberdade "de" ser impulsionado "para" ser responsável, para ter consciência. (FRANKL, 2016b, p. 48)

Liberdade e responsabilidade andam lado a lado nessa perspectiva, e como eixo articulador dessas instâncias temos a consciência (Gewissen), que é apresentada por Frankl (2016b) como "órgão do sentido". Além disso, o autor também destaca a transcendência como fator predominante na ação consciente. Segundo ele, o ser humano só pode ser servo de sua própria consciência quando percebe a mesma como um fenômeno que transcende a mera condição humana e, assim, torna-se possível interpretar a existência a partir da transcendência. (FRANKL, 2016b).

Nessa interpretação, a consciência (Gewissen) tem relevância tanto quanto o próprio sentido de vida proposto pelo autor, porque para ele "ela própria 'é' a voz, a voz da transcendência" (FRANKL, 2016b p. 49). É através desse órgão que o homem pode ultrapassar as barreiras de sua liberdade mediante os condicionamentos impostos a ele; por isso, na concepção de nosso autor ela é concebida como órgão do sentido que equilibra liberdade e responsabilidade. Desse modo, Frankl (2016b, p. 50) acrescenta que "para explicar a condição humana de ser livre é suficiente basear-nos na sua existencialidade; porém, para explicar a condição humana de ser responsável, precisamos recorrer à transcendentalidade de ter consciência".

\section{Diálogo entre Viktor Frankl e o ateísmo}

No livro de Nietzsche (2002), intitulado: Assim falava Zaratustra, o autor anuncia a morte de Deus: "Será possivel que este santo ancião ainda não ouvisse no seu bosque que Deus Já morreu?" (2002, p.12). Em decorrência, propõe o conceito de Super-homem (Übermensch), que é pouco esclarecido em sua obra (BILATE, 2014), apontando que o homem deve ser superado:

Eu anuncio-vos o Super-homem!

O Super-homem é o sentido da terra. Diga a vossa vontade: seja o Super-homem, o sentido da terra.

Exorto-vos, meus irmãos, a permanecer fieis à terra e não acreditar naqueles que vos falam de esperanças supra-terrestres (NIETZSCHE, 2002, p. 13).

Segundo Marton (1999), a consequência imediata da morte de Deus, na obra de Nietzsche, teria sido a ruptura da imagem do homem como uma criatura perante o seu Criador. Logo, torna-se necessário desconstruir os valores tradicionais e reinventar novos valores que estejam em conformidade com a terra, com a vida e com o corpo.

Se Deus está morto, então tudo será permitido? Esse questionamento aparece implicitamente no clássico russo: Os irmãos Karamázov, onde se encontra a seguinte passagem:

[...] ele (Ivan Fiodorovitch Karamazov] declarou em tom solene que em toda a face da terra não existe absolutamente nada que obrigue os homens a amarem 
seus semelhantes, que essa lei da natureza, que reza que o homem ame a humanidade, não existe em absoluto e que, se até hoje existiu o amor na Terra, este não se deveu a lei natural, mas tão só ao fato de que os homens acreditavam na própria imortalidade. Ivan Fiodorovitch acrescentou, entre parênteses, que é nisso que consiste toda a lei natural, de sorte que, destruindo-se nos homens a fé em sua imortalidade, neles se exaure de imediato não só o amor como também toda e qualquer força para que continuem a vida no mundo. $E$ mais: então não haverá mais nada amoral, tudo será permitido, até a antropofagia. Mas isso ainda é pouco, ele concluiu afirmando que, para cada indivíduo particular, por exemplo, como nós aqui, que não acredita em Deus nem na própria imortalidade, a lei moral da natureza deve ser imediatamente convertida no oposto total da lei religiosa anterior, e que o egoísmo, chegando até ao crime, não só deve ser permitido ao homem, mas até mesmo reconhecido como a saída indispensável, a mais racional e quase a mais nobre para a situação (DOSTOIÉVSKI, 2008, p. 109).

Camus (1942) compreende que a posição de Ivã Karamázov seria equivocada, pois se pode ser moral até mesmo por oposição, assim sendo, a constatação de que Deus estaria morto não autoriza toda permissividade de atos. Destarte, assevera que: "A certeza de um Deus que daria seu sentido à vida ultrapassa de muito, em atrativo, o poder impune de fazer o mal" (Camus, 1942, p. 86). A esse respeito, Comte-Sponville (2009) afirma que aquele que não transgride apenas por medo de uma sanção divina não teria valor moral, pois sua intenção não é movida nem por amor, nem por um dever. De fato, para Frankl (1978), este seria o Deus que estaria morto na modernidade, aquele que seria fruto de uma imagem infantilizada, conforme afirma:

[...] as crianças pequenas imaginam Deus como um ancião de barbas brancas e modos distintos, correspondente ao condicionamento psicológico da imaginação humana e as 'crianças grandes' - os pais dos pequenos - imaginam Deus como um 'absoluto' nebuloso, em conformidade com o condicionamento sociológico de suas imaginações (FRANKL, 1978, p. 220).

Schopenhauer (2001) já argumentava que por meio do nascimento, o homem viria do nada, e na morte, voltaria para o nada. Segundo o autor, a morte e o nascimento possuiriam a mesma natureza e significado, por conseguinte, as religiões seriam antídotos contra a realidade da mortalidade humana. Já para Sartre (2017) a negação de Deus se justifica na medida em que o seu pensamento nega a possibilidade de uma essência humana a priori. Ao conceber que a existência precede a essência, pressupôs que não existiria um Deus para conceber tal essência. Em suas palavras, afirma: "[...] se eu suprimi o Bom Deus, alguém tem que criar os valores. Temos que encarar as coisas como elas são. $E$, além disso, dizer que nós determinamos os valores não significa outra coisa senão que a vida não tem sentido, a priori." (Sartre, 2017, p. 42).

Frankl (2016b), comentando acerca da postura de Sartre, considera que o fato de construir a si mesmo sem nenhuma referência metafísica seria similar ao ilusionismo do faquir que sobe em uma corda que ele mesmo lançou no ar. De forma análoga, Sartre teria projetado o ser humano no nada ao subtrair o seu dever-ser transcendente.

Eucken (1973), por sua vez, adverte que na aurora da modernidade o mundo imediato foi se tornando o centro gravitacional da vida, enquanto que a preocupação com a salvação da alma foi gradativamente relegada a uma preocupação periférica. Na medida em que a existência de Deus se tornou incerta, os sistemas religiosos foram abalados como fontes de sentidos e valor da vida. Por conseguinte, ao rejeitar uma finalidade metafísica do mundo, o caminho possível foi a orientação para si mesmo, para potencializar a felicidade imediata.

Embora Frankl (1990) admita que o homem religioso encontraria um sentido na vida mais facilmente, quando comparado ao homem não religioso, ao mesmo tempo compreende 
que, igualmente, tanto o homem religioso quanto o não religioso buscam sentidos e podem realiza-se existencialmente independentemente dos seus sistemas de crenças.

Frankl (2011) aventou que quando o ser humano se via como criatura, se autocompreendia como a imagem de seu criador. Entretanto, na modernidade ele se vê como criador e logo se projeta como imagem de sua própria criação: a máquina. Assim, em vez de Übermensch a morte de Deus resultou em um homo machine. Em vez de Übermensch, Frankl (1990) propõe o conceito de Übersinn (Supersentido), transmudando o Über do sujeito para o sentido. Übersinn significa um sentido mais amplo que não pode ser apreendido pela pura razão, mas por via da intuição ou da fé.

Nessa perspectiva, o autor em foco não reduz o fenômeno da fé como uma fé em Deus, mas como uma crença no sentido. A fé no Übersinn é uma sensação ou crença incondicional que a vida, em todas as suas circunstâncias (trágicas ou positivas), possui um sentido mesmo quando não é apreendido em sua totalidade.

Einstein (1981) compreendia que apenas aqueles que tivessem um espírito religioso responderiam as indagações acerca do sentido da vida. Entretanto, Frankl entende a fé no sentido como uma crença natural:

Nós nada mais podemos senão aceitar que a Natureza deve ter pensado algo quando ela determinou que procurássemos pelo sentido, numa palavra, que ela própria deve, por seu lado, ter perseguido um sentido, ainda que possa ser pouco interrogado por nós sobre a sua origem (FRANKL, 1990, p. 55).

Como não é humanamente possível saber se Deus existe ou não, pois ambas as possibilidades são plausíveis, Frankl (1978) deixa essa escolha nas mãos do próprio ser humano, posto que ele é o único ente que decide livremente e, por conseguinte, se implica existencialmente.

A existência de Deus ou sua não-existência são pensamentos igualmente possíveis, ainda que não necessários. Posso ser forçado a saber algo, mas nunca a acreditar nele. A crença começa justamente quando se escolhe livremente, quando se necessita de uma decisão que favoreça ou um ou outro dos termos da alternativa, quando os pratos da balança dos prós e dos contras estão em igualdade de condições, no mesmo nível. É quando, então, aquele que escolhe lança o seu próprio peso na balança, o peso de sua própria existência (FRANKL, 1978, p. 275)

Outra distinção entre o homem religioso e irreligioso que o autor fornece está ancorada na transcendência ou imanência da consciência. Para o homem não religioso, a "voz da consciência" é imanente à facticidade psicológica, e em sua autocompreensão, torna-se responsável perante a sua própria consciência. Já na perspectiva do homem religioso, a "voz da consciência" é interpretada como o eco do transcendente e, por conseguinte, torna-se responsável perante o seu próprio Deus (Frankl, 2016b). O autor considera as várias interpretações acerca de um mesmo fenômeno, por isso ele ressalta que sobre esse fenômeno da "voz da consciência" ocorrerá uma interpretação distinta da parte do teísta e da parte do ateísta, como ele mesmo apresenta a seguir:

[FRANKL] $O$ ateu dirá simplesmente que isto é ridículo, que isto é um solilóquio, que eu falo comigo mesmo. O psicanalista dirá que nós dialogamos com nosso superego. Um outro dirá que nós falamos com nossa consciência. E o homem religioso dirá simplesmente eu falo com Deus. (FRANKL; LAPIDE, 2014, p. 113-114) 
Para o autor em tela, não importa quem está certo, por esse motivo, afirma que " Se Deus existe, então Ele não levará a mal quando alguém o confunde com o próprio eu e lhe dá um novo nome" (FRANKL; LAPIDE, 2014, p. 113). Observa-se que ao iniciar sua afirmação com a palavra "se", ele nem afirma nem nega a existência de Deus, pois faz uma suspensão do juízo ou uma epoché. $O$ homem religioso deveria então respeitar as diversas possibilidades de interpretação da "voz da consciência", pois é justamente ele quem acredita que Deus teria constituído o ser humano como um ser livre, aquela liberdade radical que abarca também a escolha em negar o próprio "criador" (Frankl, 2016b) ou atribuí-la com qualquer nome.

[FRANKL] Quando um homem, mesmo um ateísta, tem monólogos muito íntimos consigo mesmo, e "intimo" significa com absoluta sinceridade e com absoluta franqueza, ou seja, sem nenhuma consideração - quando nós realmente não enganamos a nós mesmos, então nós temos o direito de chamar de Deus quem ou aquilo a que nos dirigimos aqui. (FRANKL; LAPIDE, 2014, p. 113)

O autor oferece também uma metáfora referente a montanha para clarificar a bifurcação entre o homem religioso e irreligioso:

É como se tivesse chegado a um pico imediatamente inferior ao mais alto. Por que não vai adiante? É porque não quer perder 'o chão firme sob os pés', pois o verdadeiro não está visível para ele, está oculto na neblina, e nesta neblina, nessa incerteza, ele não se arrisca a penetrar. Somente a pessoa religiosa assume este risco. (FRANKL, 2016b, p. 53)

Entretanto, um pico inferior ou mais alto não significa necessariamente uma relação hierárquica, apenas demonstra que, no pensar de Frankl, o homem religioso se aprofunda numa relação com um Deus desconhecido e oculto. Mas, isso não significa que "assumir o risco" indique qualquer tipo de superioridade, isso simplesmente demonstra que o homem irreligioso não quer ir adiante, posto que ele possua a liberdade de escolher até onde quer seguir. Ademais, o ser humano não pode crer por meio de uma exigência, conforme assevera Frankl (2015).

\section{Logoterapia e religião: interlocuções com o ateísmo na visão de Viktor Frankl}

A logoterapia proposta por Viktor Frankl concebe a religião como um objeto, consequentemente "tanto a existência religiosa como a irreligiosa são, em princípio, fenômenos coexistentes" (FRANKL, 2015, p. 85). Dessa forma, percebe-se que para o autor tanto a experiência religiosa como a irreligiosa estão postas num mesmo plano, sem que haja privilégios para o trato da questão da religiosidade.

Esse fato nos remete à posição neutra da logoterapia perante esse objeto, pois, conforme nos esclarece Frankl (2015, p. 85) "o objetivo da psicoterapia é a cura psíquica - o objetivo da religião, contudo, é a salvação da alma". Sendo assim todos os fenômenos humanos relacionados a esse objeto são relevantes para o psicoterapeuta, pois independente de uma prática religiosa ou não, o que importa para o referido profissional é a forma com a qual esses fenômenos possam afetar psicologicamente seu paciente.

Assim, destaca-se que a "psicoterapia deve mover-se, portanto, além da fé na revelação, e a pergunta do sentido deve dar uma resposta aquém da linha que separa de um lado a concepção teísta de mundo e, de outro, a concepção ateísta" (FRANKL, 2015, p. 88 - grifos nossos). Com essa afirmação, o autor em tela nos demonstra que a linha tênue que poderia diferenciar as concepções teístas e ateístas está fundamentada no sentido. Enquanto para o teísta esse sentido pode estar vinculado inclusive à sua relação com seu deus, pois "há pessoas, 
no entanto, que não interpretam suas vidas simplesmente como uma tarefa a elas designada, mas também em função do contramestre que Ihes atribuiu a tarefa" (Frankl, 2016a, p. 134).

Na obra "A busca de Deus e questionamentos sobre o sentido" elaborada a partir de um diálogo entre Viktor Frankl e o teólogo Pinchas Lapide, encontram-se mais algumas nuances acerca do tema religião. Nele encontramos uma das abordagens de Frankl sobre o referido tema, conforme nos indica Alexander Batthyany destacando que,

Em relação à posição da Logoterapia sobre a religião é possivel registrar três afirmações fundamentais [...] em primeiro lugar, Frankl reconhece o papel legítimo que a religiosidade pode ter ou não na vida do indivíduo; em segundo lugar ele também lhe concede historicamente o significado, que lhe corresponde como expressão da busca humana pelo sentido; e em terceiro lugar ele a mantém fora da terapia aplicada, como é indicado em relação à necessária distância ideológica do médico do terapeuta. (BATTHYANY, 2014, p. 43-44)

Constata-se na afirmação do autor que, para a Logoterapia, a religiosidade tem sua relevância inclusive pelo seu significado historicamente construído, mas que ela (a religião) precisa estar distante da terapia, ou seja, religião e terapia não podem ser vistas sob a ótica do terapeuta e/ou influenciada pela sua perspectiva ideológica, ela precisa ser vista e tratada sempre de acordo com a percepção/relação que tem com o paciente.

Além disso, na mesma obra supracitada o diálogo realizado entre Frankl e Lapide (2014) contempla o tema ateísmo, iniciando pelas categorias destacadas por Lapide:

A maioria pertence a três agrupamentos: Os anticlericais, que são revoltados contra os chamados representantes de Deus, e que de fato culpam Deus por tudo aquilo que seu pessoal aqui na Terra fez de errado. Em segundo os pseudoateus, que estão irritados com o pequeno Deus, que Ihes foi imposto em casa ou na escola, porque ele não tem absolutamente nada com a necessidade de crer, que tortura seus corações. O terceiro grupo é o dos antiteístas - esta é uma especialidade judaica -, que brigam com Deus, porque não querem perdoá-lo pela existência do mal no mundo, porque a imagem de Deus, que eles têm em sua cabeça, não pode estar de acordo com Auschwitz, com toda desgraça do mundo com crianças que sem culpa vêm ao mundo mutiladas. (FRANKL; LAPIDE, 2014, p. 63 - grifos nossos)

Frankl acrescenta mais uma categoria o ateísmo moral, segundo nosso autor é preciso considerar "uma quarta coisa, que mobiliza um ateísta ou que não combina com a crença, e é um motivo moral: $O$ ateísta não pode suportar que a gente tenha esperança de ir para o céu quando a gente é obediente e respeitosa." (FRANKL; LAPIDE, 2014, p. 96). Ou seja, na prática do ateísmo moral é inaceitável o fato de que seja necessária uma recompensa por praticarmos a obediência e o respeito, por exemplo, pois esses princípios devem ser praticados livremente sem que recebamos algo adicional. Até porque, segundo Frankl, o ateísta deseja que "a gente seja respeitosa por sua própria vontade, ou por uma coisa ou pela vontade de outro, e não para ir para o céu. Ou, como estava escrito uma vez em um anúncio: ‘Fazer o bem rende juros - compre um bilhete desta ou daquela loteria, com o qual você pode ganhar"' (FRANKL; LAPIDE, 2014, p. 96).

Além disso, Frankl na referida obra, destaca que outros elementos podem contribuir com essa rejeição ateísta no que se refere à religião. Segundo ele, pelo menos mais dois componentes podem ser considerados nesse contexto de rejeição: a má interpretação dos teólogos e a mania de grandeza dos cientistas. De acordo com o autor, podemos compreender o aborrecimento para quem se tornou ateu ou se julga assim "consiste em duas coisas: Por um lado nesta pequeneza dos teólogos que se apegam às letras mal-entendidas e, por outro, na 
megalomania dos cientistas, principalmente daqueles cientistas que se orientam unicamente no modelo das ciências naturais" (FRANKL; LAPIDE, 2014, p. 112).

Além dessas considerações acerca do ateísmo, independente de qual categoria seja ele, Frankl (2016b, p. 116) também clarifica que em nossa vida podemos encontrar diversos sentidos e "a logoterapia lida com o sentido concreto de situações concretas, nas quais se encontra uma pessoa, por sua vez, também concreta". No entanto, ele acrescenta que esses sentidos concretos não são os únicos existentes em nossa vida e por isso delega à logoteoria, que pode ser definida como o fundamento antropológico acerca do sentido da vida - pode ser vista também como a aplicação da logoterapia em diversas áreas em diálogo com outros conhecimentos e disciplinas - por isso seria mais propícia para abordar o sentido último. De acordo com nosso autor,

A logo-teoria, porém, não trata apenas da "vontade de sentido" em geral, mas aborda ainda uma vontade de sentido último. A partir de uma análise fenomenológica conclui-se que quanto mais amplo for o sentido, menos compreensivel ele se torna. Tratando-se de um sentido último, ele escapa totalmente de uma mera compreensão intelectual. Porém o que é incompreensivel não precisa necessariamente ser inacreditável. (FRANKL, 2016b, p. 116)

Essa concepção acerca do sentido último pode ser vista como o princípio que demonstra a perspectiva de Frankl sobre o ateísmo e também sobre a religião, a primeira consideração importante à análise fenomenológica, ou seja, sem juízo de valor, pois apenas se devem levar em conta as descrições, constatações, daquilo que se encontra no fenômeno. A segunda está muito mais vinculada à crença, quando o sentido está além da compreensão intelectual, ou seja, racionalizado, mas que não necessariamente precisa ser desacreditado. Dito de outro modo, para Frankl, o sentido último, pode ser algo que não se pode apreender, mas que pode simplesmente ser crível, sem que haja necessidade de maiores explicações. Entretanto, a fé a esperança, o amor e a vontade sempre precisam de um fundamento ( $F r a n k l$, 1989 , 2015). Dessa forma, o ateu seria aquele que não encontrou um fundamento para prosseguir com a sua fé religiosa.

\section{Considerações finais}

As observações acerca do ateísmo no pensamento de Frankl foram fundamentais para a compreensão do homem em sua obra. Como se pôde constatar, o autor não se detém na realidade ontológica de Deus, mas se debruça na descrição fenomenológica tanto do fenômeno religioso quanto da questão do ateísmo. De forma geral, o tema foi relevante para clarificar a concepção do sentido da vida em uma perspectiva laica a partir do ponto de intersecção entre crentes e ateus que é a consciência (Gewissen). Considera-se, portanto, que a perspectiva de Frankl acerca do ateísmo contribui para uma reflexão harmônica e tolerante entre crentes e não crentes, teístas e ateístas tendo em conta que todo e qualquer ser humano é dotado de liberdade e responsabilidade.

Ademais, o ser humano é sempre aquele ser que decide acerca da existência ou inexistência de Deus, ou seja, é livre para interpretar qual o significado que ele atribui a voz da consciência (Gewissen] e se esta é imanente ou transcendente ao seu ser. Decide também entre permanecer na realidade visível ou se lançar em direção a uma fé em um Deus oculto. De uma forma ou de outra, a porta da religiosidade deve sempre permanecer aberta, tanto para quem a ultrapassa, que deve respeitar incondicionalmente aqueles que preferiram não a atravessar, quanto para aqueles que decidiram ficar antes da soleira da porta. 


\section{Referências}

AQUINO, Thiago Antonio Avellar. Logoterapia e análise existencial. uma introdução ao pensamento de Viktor Frankl. São Paulo: Paulus, 2013.

BATTHYANY, Alexander. A busca de Deus e questionamentos sobre o sentido: sobre esse livro. IN: FRANKL, Viktor E.; LAPIDE, Pinchas. A busca de Deus e questionamentos sobre o sentido: um diálogo. Trad. Márcia Neuman. 2 ed. Petrópolis, RJ: Vozes, 2014, p. 37-42.

BILATE, D. Nietzsche, entre o Übermensch e o Unmensch. In: Cadernos Nietzsche, 34, 2014, p. 215-229.

BRUZZONE, Daniele. Afinar la consciência. Educación y búsqueda de sentido a partir de Viktor E. Frankl. Buenos Aires: San Pablo, 2011.

CAMUS, A. O mito de Sísifo. Ensaio sobre o absurdo. [Trad. M. Gama] Rio de Janeiro: Editora Guanabara, 1942.

COMTE-SPONVILLE, A. O espírito do ateísmo. [Trad. E. Brandão]. São Paulo: Martins Fontes, 2009.

DOSTOIÉVSKI, F. Os irmãos Karamázov. [Trad. P. Bezerra] São Paulo: Editora 34, 2008.

EUCKEN, R. O sentido e o valor da vida. [Trad. J. Távora]. Rio de Janeiro: Editora Opera Mundi, 1973.

FRANKL, V. E.. Um sentido para a vida. psicoterapia e humanismo. Trad. Victor Hugo Silveira Lapenta. Aparecida, SP: Editora Santuário, 1989.

1990.

A questão do sentido em Psicoterapia. [Trad. Jorge Mitre]. Campinas, SP: Papirus,

. O que não está escrito nos meus livros. memórias. Trad. Cláudia Abeling. São Paulo: É Realizações, 2010.

. A vontade de sentido. fundamentos e aplicações da logoterapia. Trad. Ivo Studart

Pereira. São Paulo: Paulus, 2011.

. Em busca de sentido. Trad. W. O. Schlupp e Carlos C. Aveline. 40 ed. São Leopoldo:

Sinodal; Petrópolis: Vozes, 2016 a.

. A presença ignorada de Deus. Trad. Walter O. Schlupp e Helga H. Reinhold. 17 ed.

São Leopoldo: Sinodal; Petrópolis: Vozes, $2016 \mathrm{~b}$.

. Fundamentos antropológicos da psicoterapia. Trad. R. Bittencourt.

Rio de Janeiro: Zahar, 1978.

. O sofrimento de uma vida sem sentido. caminhos para encontrar a razão de viver.

Trad. Karleno Bocarro. São Paulo: É Realizações, 2015. 
FRANKL, Viktor E..; LAPIDE, Pinchas. A busca de Deus e questionamentos sobre o sentido. um diálogo. Trad. Márcia Neuman. 2 ed. Petrópolis, RJ: Vozes, 2014.

MARTON, S. A morte de Deus e a transvaloração dos valores. In: Hypnós, 5, 1999, p. 133-143.

NIETZSCHE, F. Assim falava Zaratrusta. [Trad. José Mendes de Souza]. Versão para E-book. 2002. Disponível em: http:/ / www.ebooksbrasil.org/adobeebook/zara.pdf Acesso em: 20 jul. 2018.

PETER, Ricardo. Viktor Frankl. a antropologia como terapia. Trad. Thereza Christina Stummer. São Paulo: Paulus, 1999.

SARTRE, J. P. O existencialismo é um humanismo. [Trad. João Batista Kreuch] 4 ed. Petrópolis, RJ: Vozes, 2014.

SCHOPENHAUER, A. Da morte, Metafísica do amor, do sofrimento do mundo. [Trad. P. Nassetti]. São Paulo: Editora Martin Claret, 2001.

VISIERS WÜRTH, Cristina. Logoterapia y religion en España. In: NOUS. Boletin de Logoterapia y Análises Existencial. Número 11, Otoño, 2007, p. 39-50.

WALTERS, Kerry. Ateísmo: um guia para crentes e não crentes. São Paulo: Paulinas, 2015.

XAUSA, Izar Aparecida de Moraes. Viktor E. Frankl entre nós. a história da Logoterapia no Brasil e integração pioneira da Logoterapia na América Latina. Porto Alegre: EDIPUCRS, 2012. 